\title{
Öğretmen Adaylarının İletişim Becerileri ile Sınıf Yönetimi Yeterlik Algıları
}

\author{
Arasındaki İlişkinin İncelenmesi* \\ Bahadır GÜLBAHAR ${ }^{* * *}$ Sadık Yüksel SIVACI ${ }^{* * *}$
}

Öz: Bu araştırmanın amacı, öğretmen adaylarının iletişim becerileri ile sınıf yönetimi yeterlik algıları arasındaki ilişkinin incelenmesidir. Araştırmanın çalışma grubu, uygun örnekleme yöntemi ile seçilmiş 504 öğrenciden oluşmaktadır. Araştırmada veri toplama aracı olarak kişisel bilgi formu, “İletişim Becerileri Ölçeği” ve “Aday Öğretmenlerin Sınıf Yönetimi Yeterlikleri Ölçeğì” kullanılmıştır. Araştırmada, cinsiyet değişkenine göre iletişim becerileri ile sınıf yönetimi yeterlik algılarının anlamlı bir farklılık göstermediği; öğrenim görülen bölümden memnuniyet değişkenine göre iletişim becerileri algılarının istatistiksel olarak anlamlı bir farklılık göstermediği, sınıf yönetimi yeterlilik algısında ise öğrenim gördükleri bölümden memnun olanların lehine istatistiksel olarak anlamlı bir farklılık olduğu; öğrenim görülen ana bilim dalı değişkenine göre iletişim becerilerinin ve sınıf yönetimi yeterlik algılarının anlamlı bir farklılık göstermediği ve artan iletişim becerilerinin sınıf yönetimi yeterlik algısında artışı sağladığı sonuçlarına ulaşılmıştır.

Anahtar Kelimeler: Öğretmen eğitimi, iletişim becerileri, sınıf yönetimi.

\footnotetext{
*Bu çalışma 1. Uluslararası Sosyal Bilimler ve Eğitim Araştırmaları Sempozyumu'nda sözlü bildiri olarak sunulmuştur.

**Yrd. Doç. Dr., Ahi Evran Üniversitesi Eğitim Fakültesi, ORCID Num.: 0000-0002-7040-1593 bahadirgulbahar@hotmail.com.

***Yrd. Doç. Dr., Ahi Evran Üniversitesi Eğitim Fakültesi, ORCID Num.: 0000-0002-9002-3155 sysivaci@ahievran.edu.tr.
}

\begin{tabular}{lll}
\hline Gönderim:22.11.2017 & Kabul:14.02.2018 & Yayın:25.04.2018 \\
\hline
\end{tabular}




\title{
Reviewing the Relationship between Preservice Teachers' Communication Skills and \\ Classroom Management Competency Perceptions
}

\begin{abstract}
The purpose of this study is to review the relationship between preservice teachers' communication skills and classroom management competency perceptions. Working group of the study consists of 504 students selected via convenience sampling method. Personal information form, "Communication Skills Scale" and "Preservice Teachers' Classroom Management Competency Scale" were used as data collection tools. In the study, it was concluded that there was no significant difference in communication skills and classroom management competency perceptions according to the variable of gender; no statistically significant difference in communication skills perceptions according to the variable of satisfaction with graduation department; a statistically significant difference in classroom management competency perceptions on behalf of those who were satisfied with their departments; no significant difference in communication skills and classroom management competency perceptions according to the variable of department and the increasing communication skills led to an increase in classroom management competency perceptions.
\end{abstract}

Keywords: Teacher education, communication skills, classroom management.

\section{Giriş}

Duygu ve düşünceleri karşılıklı olarak iletme şeklinde tanımlanabilecek iletişimin, insanlar için oldukça önemli bir güç olduğu söylenebilir. Zira iletişim, insanlara kendilerini anlatma ve tanıtma, diğer insanları anlama ve tanıma imkânı sağlar. İnsanların birbirleriyle ilişki kurmaları, başka insanlarca nasıl algılandıklarını öğrenmeleri de iletişimle mümkündür. İletişimin varlığından söz edebilmek için karşılıklılık koşulunun sağlanması gerekir. Gürüz ve Temel-Eğinli (2013), iletişimin tam olarak gerçekleşebilmesi için karşı tarafı etkilemenin de 
gerekli olduğu üzerinde durmuştur. İnsana özgü olan iletişim, gönderici durumundaki kişinin, çevresinden algıladığı bir olayı, bir veriyi, bir iletiyi kodlaması, belli bir kanal ya da araçla alıcı durumundaki hedef kişi ya da kitleye göndermesi; hedef kişi veya kitlenin de algıladığı kodu çözerek, anlaşılıp anlaşılmadığını belirterek, geri bildirimi kodlayarak göndericiye iletmesi sürecidir (Oskay, 1999; Usluata, 1995). Bu ileti alışverişinde gönderici ve alıcının ortak bir paydada, bir bağlamda buluşması gerekmektedir. İletişim, bir bağlam içinde meydana gelir. Bağlam, bir söz ya da davranışın içinde geliştiği ve ona anlam kazandıran çevre olarak tanımlanır (Küçük, 2012). Bağlamda buluşulamazsa iletişim gerçekleşemez. Bu bilgiler 1şığında, iletişim unsurlarının gönderici, alıcı, ileti, kanal, geri bildirim ve bağlam olduğu anlaşılmaktadır.

İletişim, Fransızca “communication” kelimesinin Türkçe karşılığıdır. "Communication” kelimesi "ortaklığı, toplumsallaşmış olmayı, birlikteliği, ortak katılımı" ifade eden Latince kökenli “communis” kelimesinden türetilmiştir (İnceoğlu, 2004). TDK (2017) iletişimi, “duygu, düşünce veya bilgilerin akla gelebilecek her türlü yolla başkalarına aktarılması, bildirişim, haberleşme" şeklinde tanımlamıştır. Cüceloğlu (2016)'na göre iletişim, anlam alışverişi iken Lasswell (2007) iletişimin “Kim, hangi kanal ve etkiyle, kime, ne diyor?” soruları etrafinda şekillenen bir eylem olduğunu belirtmiştir. Gürüz ve Temel-Eğinli (2013) iletişimi; bilgi, duygu ve düşüncelerin paylaşılması, aynı zamanda kişi ya da grupların davranış ve tutumlarını etkilemeye yönelik bir eylem olarak tanımlamaktadır. Tutar ve Yılmaz (2010)'a göre bireysel bir davranış olan iletişim; aynı zamanda toplumdaki huzuru sağlayan, sosyal hayatı düzenleyen bir olgu, toplumun temelini oluşturan bir sistem, örgütsel ve yönetsel yapının düzenli işleyişini sağlayan bir araç, bireysel davranışları görüntüleyen ve etkileyen bir teknik, sosyal süreçler bakımından zorunlu bir bilim, sosyal uyum için gerekli bir sanattır. Tanrıkulu (2002) ise bireylerin ve örgütlerin içinde bulundukları toplumsal sistemde ve bu sistemdeki diğer birey ve örgütlerle aralarında olması gereken uyum ve etkileşimi sağlayan temel bir süreç 
olduğunu vurgulayarak iletişimin toplumsal anlaşmada ve uyumdaki etkisinin altını çizmektedir. Bu görüşlerden hareketle, iletişimin insanoğlu için çok önemli bir ihtiyaç, varlığının çok önemli bir göstergesi, kendini ifade edebilmenin en etkili aracı ve sorunlarının en etkili çözüm yollarından biri olduğunu söylemek mümkündür. İnsanlığın gelişiminin de büyük ölçüde iletişime bağlı olduğu yine bu bilgilerden hareketle ifade edilebilir. Zira iletişim insanoğluna, duygu ve düşüncülerini, bildiklerini ve öğrendiklerini kayıt altına alma, bunları sonraki kuşaklara aktarma fırsatı sunmaktadır.

İnsanların birbirleriyle anlaşma, birbirleriyle ilişkilerini geliştirme, sorunlarına çözüm bulma ve kendilerini ifade etmelerinin anahtarı iletişimdir. Ancak bu sonuçlara ulaşılabilmesi, bireyler arasında iyi, etkili bir iletişimin gerçekleşmesine bağlıdır. İletişimde, taraflar birbirlerini açıkça anlayabiliyor, mesajlarını iletirken muhataplarının özelliklerini dikkate alıyor, birbirleriyle iletişimi devam ettirme isteği duyuyor ve iletişim sırasında birbirlerinin haklarını gözetiyorlarsa bu iletişim biçiminin etkili olduğundan söz edilebilir. Etkili bir iletişim için bireylerin benimsemeleri gereken bazı ilkeler vardır. Bu ilkeler şöyle sıralanabilir:

- $\quad$ Bireyin kendine özgü özellikleri ile değerli olduğuna inanması

- $\quad$ Bireyin iletişim kurduğu kişiyi koşulsuz kabul etmesi

- Bireyin sorunlarını kendisinin çözebileceğine inanması

- $\quad$ Bireyin kendini olduğu gibi göstermesi

- $\quad$ Bireyin duygu, düşünce ve davranışlarında tutarlı olması

- Bireyin empatiyle karşısındakinin sorunlarına onun gibi bakabilmesi, onun hissettiklerini yaşayabilmesi (Cüceloğlu, 2002).

Günümüzde öğretmenlerden beklenen en önemli becerilerden biri de ilişki kurdukları, etkiledikleri bütün insanlarla, özellikle de meslektaşları, okul yöneticileri, öğrencileri ve öğrencilerin aileleriyle etkili iletişimlerinin olmasıdır. Öğretmenlerin etkili iletişimci olmaları, paydaşlar arası ilişkilerin gelişmesi, okulların gelişmesi, eğitim kalitesinin yükselmesi 
bakımından oldukça önemli bir etkendir. Eğitimde yaşanan birçok sorunun çözümünün de öğretmenlerin iletişimdeki başarılarına bağlı olduğu savunulabilir. Bu bağlamda öğretmen adaylarının iletişim becerileri edinmiş, iletişim becerilerini etkili kullanabilen, iletişim uzmanı kişiler olmaları büyük önem arz etmektedir. Gordon’a (1996, s. 17-27), göre, öğretmenin sınıfta edindiği role yönelik önceden sahip oldukları inançları sınıf içindeki iletişim örüntüsünü belirlemede etkilidir. Özellikle bazı yerleşmiş kalıp cümleler ya da inançlar (Ör: "İyi öğretmen tüm soruların yanıtını bilir, öğrencilerden daha akıllı ve bilgilidir, İyi öğretmen tutarlıdır, hata yapmaz, aşırı tepkilerde bulunmaz, İyi öğretmen gerçek duygularını öğrencilerine göstermez ve İyi öğretmen sakindir, her zaman soğukkanlıdır, telaşlanmaz, sinirlenmez) öğretmenin sınıftaki rolünü belirlemekte ve bu durum öğrenciler ile gerçekleştirdikleri iletişime yansımaktadır (Gürşimşek, 1999). Öğretmen ile öğrenci arasında var olan etkili iletişimin temelini oluşturan inançlar ise; empatik anlayışı, içtenlik ve açıklığı, koşulsuz kabul ve saygıyı gerektirmektedir (Gürşimşek, 1999).

Sınıf yönetimi, öğretme-öğrenme etkinliklerinin verimliliğini yükseltmek için gerçekleştirilen rasyonel bir eylemdir. Bu eylem, önceleri öğretmen otoritesinin sınıfta hâkim kılınması anlamında disipline dayanan bir görüşü ifade ediyorken günümüzde daha çok öğrenmeyi sağlayıcı, destekleyici bir sınıf ortamını yaratma çabası anlamında kullanılmaktadır (Demirel, 2006). Brophy’ye (1988) göre sınıf yönetimi, öğretim hedeflerine ulaşmak için öğrenme çevresinin yaratılması, korunması ve yönetilmesi etkinlikleri iken Lemlech (1988) sınıf yönetimini, sınıf yaşamının bir orkestra gibi yönetilmesi şeklinde tanımlamıştır. Celep (2002) ise sınıf yönetimini, sınıfın amacını gerçekleştirmek için öğretim kaynakları ile öğrencileri eş güdümleyerek harekete geçirme süreci olarak tanımlamıştır. Demirtaş'ın (2009) sınıf yönetimi tanımı, sınıftaki insan kaynakları olan öğrenciler ile maddî kaynaklar olan araçgereçlerin sınıfın amaçları doğrultusunda harekete geçirilmesi şeklindeyken Erdoğan (2010) da sınıf yönetiminin planlama, örgütleme, uygulama ve değerlendirme fonksiyonlarına ilişkin ilke, 
kavram, kuram, model ve tekniklerin sistematik ve bilinçli olarak uygulanmasıyla ilgili etkinliklerin tümü olduğunu ifade etmiştir. Tanımlardan da anlaşılacağı üzere, sınıf yönetiminde temel amaç, olumlu ve verimli bir öğrenme ortamı yaratarak öğrencilerin öğretim hedeflerine ulaşmalarını sağlamaktır.

Sınıf yönetimi, öğretmenden beklenen rollerden biridir. Yönetim açısından sınıf ikliminde öğretmen, hedeflenen amaçlara ulaşabilmek için öğrencilerin çalışmasını ve başarılı olmasını sağlayan, bu amaçla önemli görevler üstlenen kişidir (İlgar, 2005). Sınıf yöneticisi öğretmen, öğretimi kolaylaştırarak öğrencileri öğretim hedeflerine ulaştırmaya çalışan kişidir. Öğretimi kolaylaştırmanın yanı sıra öğretim zamanını arttırma, sıcak ve destekleyici bir sınıf iklimi meydana getirme ve koruma, öğrencilerin zarar verici davranışlarını önleme, istendik davranışların artması için uygun iklimi sağlama gibi amaçları gerçekleştirmeye de çalışmalıdır (Sadık, 2000). Öğretmenin, sınıfını etkili bir şekilde yönetebilmesi için bazı yeterliklere sahip olması gerekmektedir.

Sınıf yönetiminde etkili öğretmen, öğretimi planlar; öğretime gereken kaynakları örgütler; öğrencilerin ve öğrenci kümelerinin arasında koordinasyonu sağlar; kendisi ile öğrencileri arasında ve öğrencilerin birbirleri ile iletişimini gerçekleştirir; öğretim etkinliklerini ve öğrencilerin öğrenmelerini kontrol eder; öğrencilerin öğrenme edimlerini ölçer ve değerlendirir. Kısaca öğretmen sınıfının eğitim-öğretim ve yönetim sorunlarını çözmeye vakit ayırır ve karşılaştığı öğrenme sorunlarının çözümlerine rehberlik eder (Başaran, 2005). Öğrenme ve öğretme, sınıfı yönetirken öğretmenin odağındadır.

Bir öğretmenin iletişim becerilerine sahip olması, iletişim becerilerini kullanabilmesi sınıf yönetiminde başarılı olmasına, amaca ulaşmasına zemin hazırlayabilir. Zira öğrencileriyle sınıf içinde etkili iletişim kurabilen öğretmenler, sınıfta iyi ilişkiler kurulmasını, verimli bir öğretme-öğrenme ortamı oluşmasını, öğrencilerin yüksek düzeyde öğrenmelerini ve olumlu davranışlar kazanmalarını sağlayabilir. Öte yandan, sınıf yönetiminde etkili olan bir 
öğretmenden, sınıfta öğrencileriyle de iyi iletişim kurması beklenmektedir. Nitekim sınıf yönetiminin önemli boyutlarından biri de etkili iletişimdir. Ulaşılabilen alanyazında, öğretmen adaylarının iletişim becerilerini ve sınıf yönetimi yeterliklerini ayrı ayrı inceleyen araştırmalara (Kuğuoğlu, 2005; Özay Köse, 2010) rastlanmasına rağmen öğretmen adaylarının iletişim becerileriyle sınıf yönetimi yeterlikleri arasındaki ilişkiyi ele alan yalnızca bir çalışmaya (Tan ve Tan, 2016) rastlanmıştır. Eğitim-öğretimde niteliği etkileyen iki önemli değişken olduğu düşünülen iletişim becerileri ve sınıf yönetimi yeterliklerinin birbirleri ile olan ilişkisinin incelenmesi önem arz etmektedir. Bu araştırma ile birlikte öğretmen adaylarının sınıf yönetimi yeterlikleri algıları, Öğretmen adaylarının iletişim becerilerine yönelik algıları belirlenecek ve özellikle araştırmanın sonuçlarında elde edilecek bulgular yardımıyla öğretmenlerin sınıf yönetimi sürecinde iletişimlerinin nasıl olması gerektiği ile ilgili bir fikir verecektir. $\mathrm{Bu}$ sebepten dolayı bu çalışmanın ilgili literatüre katkı sağlayacağı düşünülmektedir. $\mathrm{Bu}$ çalışmanın temel amacı, öğretmen adaylarının iletişı̇m becerileri algılarının sınıf yönetimi yeterlik algılarıyla ilişkisini ortaya koymaktır. Bu amaç doğrultusunda araştırmada cevap aranan problemler şunlar olmuştur:

1. Öğretmen adaylarının sınıf yönetimi yeterliklerine ilişkin algıları ne düzeydedir?

2. Öğretmen adaylarının iletişim becerilerine ilişkin algıları ne düzeydedir?

3. Öğretmen adaylarının sınıf yönetimi ve iletişim becerilerine ilişkin algılarında demografik özelliklerin ne düzeyde etkisi vardır?

4. Öğretmen adaylarının sınıf yönetimi ve iletişim becerilerine ilişkin algıları arasında ne düzeyde ilişki vardır?

\section{Yöntem}

\section{Araştırmanın Modeli}

Araştırma, öğretmen adaylarının sınıf yönetimi yeterlik algıları ile iletişim becerileri arasındaki ilişkiyi tespit etmeye yönelik korelasyonel bir araştırma niteliğindedir. Korelasyonel 
araştırmalar, iki ya da daha çok değişken arasındaki ilişkinin herhangi bir şekilde bu değişkenlere müdahale edilmeden incelendiği, ilişkinin genel olarak betimlendiği araştırmalardır (Büyüköztürk, Çakmak, Akgün, Karadeniz ve Demirel, 2010; Fraenkel ve Wallen, 2009). Bu araştırma kapsamında korelasyonal araştırmalarının temelini oluşturan ilişkinin ortaya çıkarılması amacıyla iki değişken belirlenmiştir. Bu değişkenler öğretmen adaylarının iletişim becerileri algıları ve sınıf yönetimi yeterlik algılarıdır.

\section{Araştırmanın Örneklemi}

Araştırmaya katılan öğretmen adaylarının cinsiyet, yaş, bölüm, okul ortalamaları ve bölümden duydukları memnuniyete ilişkin bilgiler Tablo 1' de gösterilmektedir. 
Tablo 1. Ö̆gretmen Adaylarının Cinsiyet, Yaş, Bölüm, Okul Ortalamaları ve Bölümden Duydukları Memnuniyete Illişkin Bilgiler

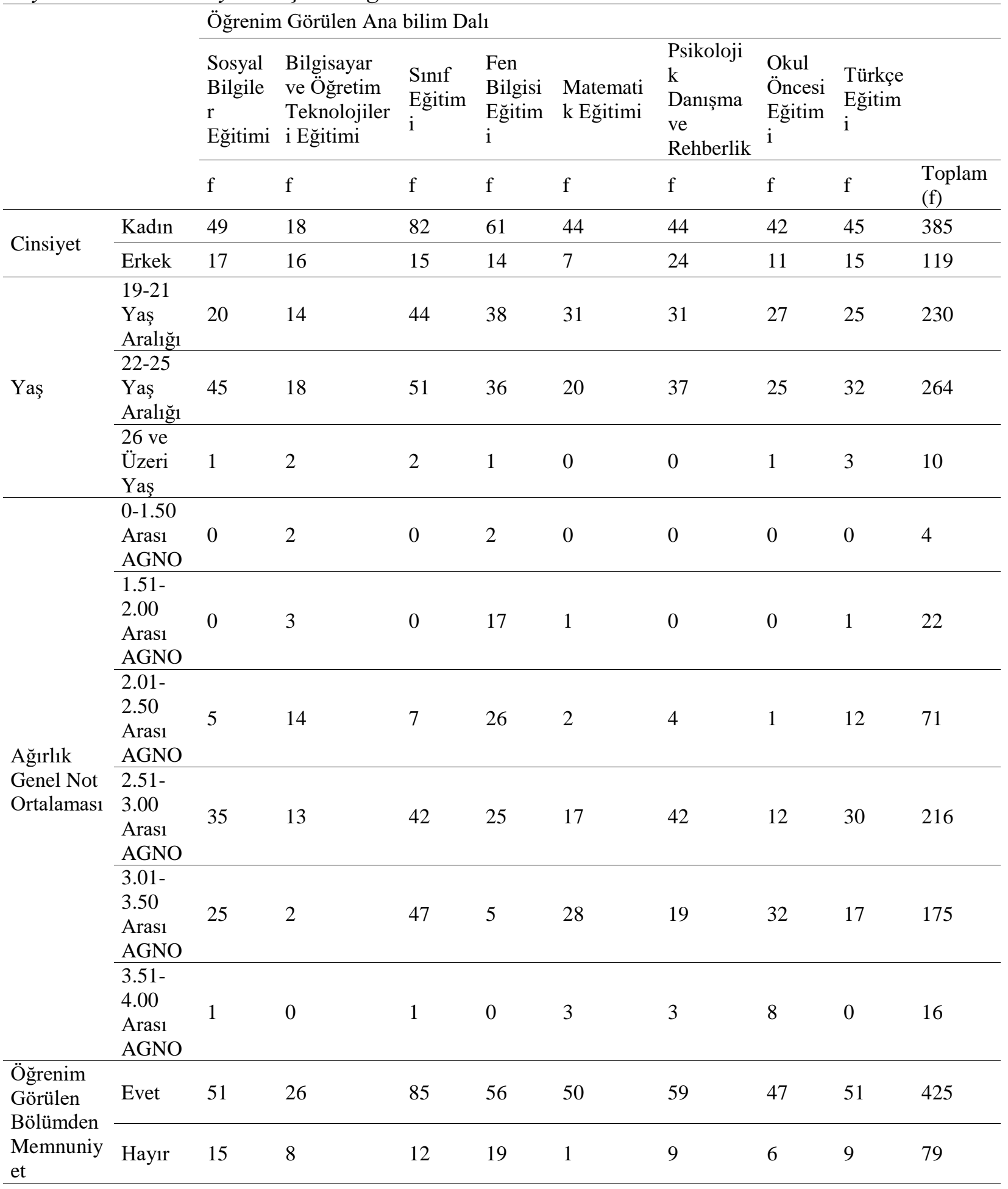

Tablo 1'de görüldüğü gibi, araştırmanın örneklemini, uygun örnekleme yöntemi ile seçilmiş 385'i $(\% 76,4)$ kadın, 119'u $(\% 23,6)$ erkek öğrenci olmak üzere toplam 504 öğrenciden 
oluşmaktadır. Ulaşılabilirlik ve elverişlilik esasına dayalı olan uygun örnekleme yöntemi, bazı araştırma konularında bilgilerin hızlıca toplanması amacıyla tercih edilen bir yöntemdir (Aypay, 2010). Araştırmaya katılan öğretmen adaylarının içerisinde 230 kişi '19-21 Yaş Aralığında', 264 kişi '22-25 Yaş Aralığında' ve 10 kişide '26 ve Üzeri Yaş' aralığında' bulunmaktadır. Çalışma grubunda bulunan öğrencilerin öğrenim gördükleri ana bilim dallarına (ABD) göre dağılımları incelendiğinde: Sosyal Bilgiler Eğitimi ABD'de 66 (\%13,1), Bilgisayar ve Öğretim Teknolojileri Eğitimi ABD'de 34 (\%6,7), Sınıf Eğitimi ABD'de 97 (\%19,2), Fen Bilgisi Eğitimi ABD'de 75 (\%14,9), Matematik Eğitimi ABD'de 51 (\%10,1), Psikolojik Danışma ve Rehberlik ABD'de 68 (\%13,5), Okul Öncesi Eğitimi ABD'de 53 (\%10,5) ve Türkçe Eğitimi ABD' de $60(\% 11,9)$ öğrenci olduğu görülmektedir. Öğrencilerin 4'ü $(\% 0,8)$ 0-1,50 arası Ağılıklı Genel Not Ortalamasına (AGNO), 22'si(\%4,4) 1,51-2.00 arası AGNO' ya, 71'i (\%14,1) 2.01-2.51 aras1 AGNO' ya, 216's1 (\%42,9) 2,51-3.00 aras1 AGNO' ya, 175'i $(\% 34,7)$ 3.01-3,51 arası AGNO'ya ve 16's1 (\%3,2) 3,51-4.00 aras1 AGNO'ya sahiptir. Öğrencilerin 425'i $(\% 84,3)$ öğrenim gördüğü bölümden memnun iken 79'u $(\% 15,7)$ öğrenim gördüğü bölümden memnun olmadıklarını ifade etmişlerdir.

\section{Veri Toplama Araçları}

Araştırmada veri toplama aracı olarak kişisel bilgi formu, "İletişim Becerileri Ölçeği" ve "Aday Öğretmenlerin Sınıf Yönetimi Yeterlikleri Ölçeği" kullanılmıştır.

İletişim Becerileri Ölçeği: Owen ve Bugay (2014) tarafından geliştirilen 5'li likert tipi bir ölçektir. Analizler sonucunda 25 maddeli ölçme aracının dört faktörlü yapı gösterdiği belirlenmiştir: 'iletişim ilkeleri ve temel beceriler' (10 madde), 'kendini ifade etme' (4 madde), ‘etkin dinleme ve sözel olmayan iletişim’ (6 madde) ve 'iletişim kurmaya isteklilik’(5 madde). Owen ve Bugay (2014) tarafından yapılan çalışmada Cronbach alfa iç tutarlık katsayısı .88 olarak hesaplanmıştır. Bu çalışmada da ölçeğin Cronbach alfa iç tutarlık katsayısının .90 olduğu görülmektedir. 
Aday Öğretmenlerin Sınıf Yönetimi Yeterlikleri Ölçeği: Aday öğretmenlerin sınıf yönetimi yeterlik algılarını belirlemek üzere Gökyer ve Özer (2014) tarafından geliştirilmiştir. 54 maddelik beşli Likert tipi olan ölçek, "sınıfta ilişki yönetimi” (6 madde), “öğretimin yönetimi” (6 madde) ve "öğrenciyi/çevreyi tanıma" (4 madde) olmak üzere üç alt boyuttan olauşmaktadır. Üç faktörlü yapıyı ölçen toplam varyansın 51,016 olduğu görülmüştür. Gökyer ve Özer (2014) tarafindan yapılan çalışmada ölçeğin tamamına ait Cronbach Alpha Katsayısının .93 olduğu hesaplanmıştır. Bu çalışmada da ölçeğe ait Cronbach Alpha katsayısının .88 olduğu görülmüştür.

\section{Verilerin Analizi}

Veriler SPSS paket programına işlenmiş ve çalışmada kullanılacak testleri belirlemek için normallik testi gerçekleştirilmiştir. Çalışmadan elde edilen verilerin normallik durumu Shapiro-Wilk normallik testi kullanılarak test edilmiş ve verilerin normal dağılım göstermediği sonucuna varılmıştır. Bundan dolayı iki bağımsız grubun karşılaştırılmasında Mann Whitney U testi, üç ve daha fazla bağımsız grubun karşılaştırılmasında ise Kruskal Wallis parametrik olmayan test yöntemleri kullanılmıştır. Değişkenler arasındaki ilişki düzeyinin belirlenmesinde ise Spearman Korelasyon yöntemi kullanılmıştır. Araştırma kapsamında analizleri yapılan ölçeklerin ortalama puanlarının yorumlanmasında ortalaması 4'den fazla olan boyutlar yüksek ortalamaya sahip, 2 den az olanlar ise düşük ortalamaya sahip değerler olarak kabul edilmiştir (Ateş ve Durmaz, 2016).

\section{Bulgular}

Öğretmen adaylarının sınıf yönetimi yeterlikleri algıları ölçeğine yönelik puan ortalamaları Tablo 2'de gösterilmiştir. 
Tablo 2. Öğretmenler adaylarının sınıf yönetimi yeterlikleri algıları ölçeği puan ortalamaları

\begin{tabular}{ccc}
\hline Ölçek ve alt boyutları & $\mathrm{N}$ & $\overline{\mathrm{X}}$ \\
\hline Sınıf Yönetimi Yeterlikleri Algıları & 504 & 3.88 \\
Sinıfta İlişki Yönetimi Alt Boyutu & 504 & 3.93 \\
Öğretim Yöntemi Alt Boyutu & 504 & 3.82 \\
Öğrenciyi/Çevreyi Tanıma Alt Boyutu & 504 & 3.91 \\
\hline
\end{tabular}

Tablo 2 incelendiğinde, aday öğretmenlerin sınıf yönetimi yeterlikleri ölçeğinin genelinde puan ortalamasının 3.88 olduğu görülmektedir. Ölçekte artan puanlar, artan yeterlik algısını gösterdiği gibi ölçekten alınabilecek maksimum puan 80'dir. Bu bağlamda çalışma grubunda bulunan öğretmen adaylarının sınıf yönetimi yeterlik algısı düzeylerinin yüksek olduğu söylenebilir. Alt boyutlarda da durumun paralellik gösterdiği görülmektedir. Öğretmen adaylarının iletişim becerileri ölçeğine yönelik puan ortalamaları Tablo 3'te gösterilmiştir.

Tablo 3. Iletişim becerileri ölçeği puan ortalamaları

\begin{tabular}{ccc}
\hline & $\mathrm{N}$ & $\overline{\mathrm{X}}$ \\
\hline İletişim Becerileri Genel Boyutu & 504 & 3,96 \\
İletişim İlkeleri ve Temel Beceriler Alt Boyutu & 504 & 3,97 \\
Kendini İfade Etme Alt Boyutu & 504 & 4,01 \\
Etkin Dinleme ve Sözel Olmayan İletişim Alt Boyutu & 504 & 4,03 \\
İletişim Kurmaya İsteklilik Alt Boyutu & 504 & 3,85 \\
\hline
\end{tabular}

Tablo 3 incelendiğinde, İletişim Becerileri Ölçeğinin genelinde puan ortalamasının 3.96 olduğu görülmektedir. Ölçekte artan puanlar, artan iletişim becerilerini gösterdiği gibi ölçekten alınabilecek maksimum puanı 5'tir. Bu bağlamda çalışma grubunda bulunan öğretmen adaylarının iletişim becerisi düzeylerinin yüksek olduğu söylenebilir. Alt boyutlarda da durumun paralellik gösterdiği görülmektedir. İletişim becerilerine ilişkin alt boyutlar açısından cinsiyet değişkenine göre anlamlı farklılığın olup olmadığını belirlemek üzere yapılan analize ilişkin sonuçlar Tablo 4'te gösterilmiştir. 
Tablo 4. Cinsiyet değişkenine göre iletişim becerileri

\begin{tabular}{ccccccc}
\hline & Cinsiyet & $\mathrm{n}$ & $\begin{array}{c}\text { Sıra } \\
\text { Ortalaması }\end{array}$ & $\mathrm{U}$ & $\mathrm{Z}$ & $\mathrm{p}$ \\
\hline \multirow{2}{*}{ İletişim Becerileri Genel Boyutu } & Kadın & 385 & 254.14 & 22276.500 & -.455 & .649 \\
İletişim İlkeleri ve Temel Beceriler Alt & Erkek & 119 & 247.20 & & & \\
Boyutu & Kadın & 385 & 253.41 & 22557.000 & -.253 & .800 \\
& Erkek & 119 & 249.55 & & & \\
Kendini İfade Etme Alt Boyutu & Kadın & 385 & 254.27 & 22227.500 & -.494 & .621 \\
Etkin Dinleme ve Sözel Olmayan İletişim & Erkek & 119 & 246.79 & & & \\
Alt Boyutu & Kadın & 385 & 257.59 & 20946.000 & -1.420 & .156 \\
& Erkek & 119 & 236.02 & & & \\
İletişim Kurmaya İsteklilik Alt Boyutu & Kadın & 385 & 250.87 & 22279.500 & -.455 & .649 \\
\hline
\end{tabular}

Tablo 4 incelendiğinde, cinsiyet değişkenine göre iletişim becerileri düzeylerinin istatistiksel olarak anlamlı bir farklılık göstermediği görülmektedir ( $p>.05)$. Erkeklerin “İletişim Becerileri Ölçeği” puan toplamları sıra ortalamalarının $(X=247,20)$ kadınlarınkinden $(X=254,14)$ düşük olduğu görülmektedir.

Cinsiyet değişkenine göre "İletişim İlkeleri ve Temel Beceriler" alt boyutu puan toplamları incelendiğinde istatistiksel olarak anlamlı bir farklılık göstermediği görülmektedir ( $p>$.05). Erkeklerin "İletişim İlkeleri ve Temel Beceriler" alt boyutu puan toplamları sıra ortalamalarının $(X=249,55)$ kadınlarınkinden $(X=253,41)$ düşük olduğu görülmektedir.

Cinsiyet değişkenine göre "Kendini İfade Etme" alt boyutu puan toplamları incelendiğinde istatistiksel olarak anlamlı bir farklılık olmadığı görülmektedir ( $p>.05)$. Erkeklerin "Kendini İfade Etme" alt boyutu puan toplamları sıra ortalamalarının $(X=246,79)$ kadınlarınkinden $(X=254,27)$ düşük olduğu görülmektedir.

Cinsiyet değişkenine göre "Etkin Dinleme ve Sözel Olmayan İletişim” alt boyutu puan toplamları incelendiğinde, istatistiksel olarak anlamlı bir farklılık olmadığı görülmektedir ( $p>$.05). Erkeklerin "Etkin Dinleme ve Sözel Olmayan İletişim” alt boyutu puan toplamları sıra ortalamalarının $(X=236,02)$ kadınlarınkinden $(X=257,59)$ düşük olduğu görülmektedir. 
Cinsiyet değişkenine göre "İletişim Kurmaya İsteklilik" alt boyutu puan toplamları incelendiğinde, istatistiksel olarak anlamlı bir farklılık olmadığı görülmektedir ( $p>.05)$. Erkeklerin "İletişim Kurmaya İsteklilik" alt boyutu puan toplamları sıra ortalamalarının $(X=257,78)$ kadınlarınkinden $(X=250,87)$ yüksek olduğu görülmektedir. Sınıf yönetimi yeterliklerine ilişkin alt boyutlar açısından cinsiyet değişkenine göre anlamlı farklılığın olup olmadığını belirlemek üzere yapılan analize ilişkin sonuçlar Tablo 5’te gösterilmiştir.

Tablo 5. Cinsiyet değişkenine göre sınıf yönetimi yeterlikleri algıları

\begin{tabular}{|c|c|c|c|c|c|c|}
\hline & Cinsiyet & $\mathrm{n}$ & $\begin{array}{c}\text { Sira } \\
\text { Ortalamas } 1\end{array}$ & $\mathrm{U}$ & $\mathrm{Z}$ & $\mathrm{p}$ \\
\hline \multirow{2}{*}{$\begin{array}{l}\text { Sınıf Yönetimi Yeterlikleri Algıları Genel } \\
\text { Boyutu }\end{array}$} & Kadın & 385 & 255.20 & 21868.000 & -.750 & .454 \\
\hline & Erkek & 119 & 243.76 & & & \\
\hline \multirow{2}{*}{ Sınıfta İlişki Yönetimi Alt Boyutu } & Kadın & 385 & 259.27 & 20301.000 & -1.888 & .059 \\
\hline & Erkek & 119 & 230.60 & & & \\
\hline \multirow{2}{*}{ Öğretim Yöntemi Alt Boyutu } & Kadın & 385 & 252.93 & 22743.500 & -.119 & .905 \\
\hline & Erkek & 119 & 251.12 & & & \\
\hline \multirow{2}{*}{ Öğrenciyi/Çevreyi Tanıma Alt Boyutu } & Kadın & 385 & 250.87 & 22279.000 & -.459 & .646 \\
\hline & Erkek & 119 & 257.78 & & & \\
\hline
\end{tabular}

Tablo 5 incelendiğinde, cinsiyet değişkenine göre sınıf yönetimi yeterlikleri algısının istatistiksel olarak anlamlı bir farklılık göstermediği görülmektedir ( $p>.05)$. Erkeklerin "Sınıf Yönetimi Yeterlikleri Algıları" ölçeği puan toplamları sıra ortalamalarının $(X=243,76)$ kadınlarınkinden $(X=255,20)$ düşük olduğu görülmektedir.

Cinsiyet değişkenine göre "Sınıfta İlişki Yönetimi" alt boyutu puan toplamları incelendiğinde, istatistiksel olarak anlamlı bir farklılık göstermediği görülmektedir (p>.05). Erkeklerin "Sınıfta İlişki Yönetimi” alt boyutu puan toplamları sıra ortalamalarının $(X=230,60)$ kadınlarınkinden $(X=259,27)$ düşük olduğu görülmektedir.

Cinsiyet değişkenine göre “Öğretim Yöntemi” alt boyutu puan toplamları incelendiğinde, istatistiksel olarak anlamlı bir farklılık olmadığı görülmektedir $(p>.05)$. Erkeklerin “Öğretim Yöntemi” alt boyutu puan toplamları sıra ortalamalarının $(X=251,12)$ kadınlarınkinden $(X=252,93)$ düşük olduğu görülmektedir. 
Cinsiyet değişkenine göre "Öğrenciyi/Çevreyi Tanıma" alt boyutu puan toplamları incelendiğinde, istatistiksel olarak anlamlı bir farklılık olmadığı görülmektedir $(p>.05)$. Erkeklerin “Öğrenciyi/Çevreyi Tanıma” alt boyutu puan toplamları sıra ortalamalarının $(X=257,78)$ kadınlarınkinden $(X=250,87)$ yüksek olduğu görülmektedir. İletişim becerilerine ilişkin alt boyutlar açısından öğrenim görülen bölümden memnuniyet değişkenine göre anlamlı farklılığın olup olmadığını belirlemek üzere yapılan analize ilişkin sonuçlar Tablo 6'da gösterilmiştir.

Tablo 6. Öğrenim görülen bölümden memnuniyet değişkenine göre iletişim becerileri

\begin{tabular}{ccccccc}
\hline & Memnuniyet & $\mathrm{n}$ & Sira Ortalamas1 & $\mathrm{U}$ & $\mathrm{Z}$ & $\mathrm{p}$ \\
\hline İletişim Becerileri Genel Boyutu & Evet & 425 & 256.34 & 15157.000 & -1.372 & .170 \\
İletişim İlkeleri ve Temel Beceriler & Hayır & 79 & 231.86 & & & \\
Alt Boyutu & Evet & 425 & 254.62 & 15885.000 & -.761 & .447 \\
& Hayır & 79 & 241.08 & & & \\
Kendini İfade Etme Alt Boyutu & Evet & 425 & 253.64 & 16304.500 & -.410 & .682 \\
Etkin Dinleme ve Sözel Olmayan & Hayır & 79 & 246.39 & & & \\
İletişim Alt Boyutu & Evet & 425 & 256.99 & 14877.500 & -1.615 & .106 \\
İletişim Kurmaya İsteklilik Alt & Hayır & 79 & 228.32 & & \\
Boyutu & Evet & 425 & 258.15 & 14385.500 & -2.033 & $\mathbf{. 0 4 2}$ \\
\hline & Hayır & 79 & 222.09 & & & \\
\hline
\end{tabular}

Tablo 6 incelendiğinde, öğrenim görülen bölümden memnuniyet değişkenine göre iletişim becerileri düzeylerinin istatistiksel olarak anlamlı bir farklılık göstermediği görülmektedir ( $p>.05)$. Memnun olanların “İletişim Becerileri Ölçeği” puan toplamları sıra ortalamalarının $(X=256,34)$ memnun olmayanlardan $(X=231,86)$ yüksek olduğu görülmektedir.

Memnuniyet değişkenine göre "İletişim İlkeleri ve Temel Beceriler” alt boyutu puan toplamları incelendiğinde, istatistiksel olarak anlamlı bir farklılık göstermediği görülmektedir ( $p>$.05). Memnun olanların “İletişim İlkeleri ve Temel Beceriler” alt boyutu puan toplamları sıra ortalamalarının $(X=254,62)$ memnun olmayanlardan $(X=241,08)$ yüksek olduğu görülmektedir.

Memnuniyet değişkenine göre "Kendini İfade Etme" alt boyutu puan toplamları incelendiğinde, istatistiksel olarak anlamlı bir farklılık olmadığ görülmektedir $(p>.05)$. 
Memnun olanların "Kendini İfade Etme" alt boyutu puan toplamları sira ortalamalarının $(X=253,64)$ memnun olmayanlardan $(X=246,39)$ yüksek olduğu görülmektedir.

Memnuniyet değişkenine göre "Etkin Dinleme ve Sözel Olmayan İletişim” alt boyutu puan toplamları incelendiğinde, istatistiksel olarak anlamlı bir farklılık olmadığı görülmektedir ( $p>.05)$. Memnun olanların "Etkin Dinleme ve Sözel Olmayan İletişim” alt boyutu puan toplamları sıra ortalamalarının $(X=256,99)$ memnun olmayanlardan $(X=228,32)$ yüksek olduğu görülmektedir.

Memnuniyet değişkenine göre “İletişim Kurmaya İsteklilik” alt boyutu puan toplamları incelendiğinde, istatistiksel olarak anlamlı bir farklılık olduğu görülmektedir ( $p<.05)$. Memnun olanların "İletişim Kurmaya İsteklilik" alt boyutu puan toplamları sıra ortalamalarının $(X=258,15)$ memnun olmayanlardan $(X=222,09)$ yüksek olduğu görülmektedir. Sınıf yönetimi yeterlikleri algılarına ilişkin alt boyutlar açısından öğrenim görülen bölümden memnuniyet değişkenine göre anlamlı farklılığın olup olmadığını belirlemek üzere yapılan analize ilişkin sonuçlar Tablo 7'de gösterilmiştir.

Tablo 7. Öğrenim görülen bölümden memnuniyet değişkenine göre sinıf yönetimi yeterlikleri algılart

\begin{tabular}{ccccccc}
\hline & Memnuniyet & $\mathrm{n}$ & $\begin{array}{c}\text { Sira } \\
\text { Ortalaması }\end{array}$ & $\mathrm{U}$ & $\mathrm{Z}$ & $\mathrm{p}$ \\
\hline Sınıf Yönetimi Yeterlikleri Algıları & Evet & 425 & 261.48 & 12969.000 & -3.216 & $\mathbf{. 0 0 1}$ \\
Genel Boyutu & Hayır & 79 & 204.16 & & & \\
Sınıfta İlişki Yönetimi Alt Boyutu & Evet & 425 & 262.18 & 12671.500 & -3.482 & $\mathbf{. 0 0 0}$ \\
& Hayır & 79 & 200.40 & & & \\
Öğretim Yöntemi Alt Boyutu & Evet & 425 & 259.68 & 13734.000 & -2.584 & $\mathbf{. 0 1 0}$ \\
& Hayır & 79 & 213.85 & & \\
Öğrenciyi/Çevreyi Tanıma Alt Boyutu & Evet & 425 & 259.14 & 13964.000 & -2.408 & $\mathbf{. 0 1 6}$ \\
& Hayır & 79 & 216.76 & & & \\
\hline
\end{tabular}

Tablo 7 incelendiğinde, öğrenim görülen bölümden memnuniyet değişkenine göre sınıf yönetimi yeterlikleri algısının istatistiksel olarak anlamlı bir farklılık gösterdiği görülmektedir 
$(p<.05)$. Memnun olanların "Sınıf Yönetimi Yeterlikleri Algıları” ölçeği puan toplamları sıra ortalamalarının $(X=261,48)$ memnun olmayanlardan $(X=204,16)$ yüksek olduğu görülmektedir. Memnuniyet değişkenine göre "Sınıfta İlişki Yönetimi” alt boyutu puan toplamları incelendiğinde, istatistiksel olarak anlamlı bir farklılık olduğu görülmektedir ( $p<.05)$. Memnun olanların "Sınıfta İlişki Yönetimi” alt boyutu puan toplamları sıra ortalamalarının $(X=262,18)$ memnun olmayanlardan $(X=200,40)$ yüksek olduğu görülmektedir.

Memnuniyet değişkenine göre “Öğretim Yöntemi” alt boyutu puan toplamları incelendiğinde, istatistiksel olarak anlamlı bir farklılık olduğu görülmektedir $(p<.05)$. Memnun olanların “Öğretim Yöntemi” alt boyutu puan toplamları sıra ortalamalarının $(X=251,12)$ memnun olmayanlardan $(X=252,93)$ düşük olduğu görülmektedir.

Memnuniyet değişkenine göre "Öğrenciyi/Çevreyi Tanıma” alt boyutu puan toplamları incelendiğinde, istatistiksel olarak anlamlı bir farklılık olduğu görülmektedir ( $p<.05)$. Memnun olanların "Öğrenciyi/Çevreyi Tanıma" alt boyutu puan toplamları sıra ortalamalarının $(X=259,68)$ memnun olmayanlardan $(X=216,76)$ yüksek olduğu görülmektedir. İletişim becerilerine ilişkin alt boyutlar açısından öğrenim görülen ana bilim dalı değişkenine göre anlamlı farklılığın olup olmadığını belirlemek üzere yapılan analize ilişsin sonuçlar Tablo 8'de gösterilmiştir. 
Tablo 8. Öğrenim görülen ana bilim dalı değişkenine göre iletişim becerileri

\begin{tabular}{|c|c|c|c|c|c|}
\hline & Ana bilim Dalı & $\mathrm{n}$ & $\begin{array}{c}\text { Sira } \\
\text { Ortalaması }\end{array}$ & Ki-Kare & $\mathrm{p}$ \\
\hline \multirow{8}{*}{$\begin{array}{c}\text { İletişim } \\
\text { Becerileri } \\
\text { Genel } \\
\text { Boyutu }\end{array}$} & $\begin{array}{l}\text { Sosyal Bilgiler Eğitimi } \\
\end{array}$ & 66 & 298.62 & 13.514 & .061 \\
\hline & Bilgisayar ve Öğretim Teknolojileri Eğitimi & 34 & 275.10 & & \\
\hline & Sınıf Eğitimi & 97 & 255.56 & & \\
\hline & Fen Bilgisi Eğitimi & 75 & 234.50 & & \\
\hline & Matematik Eğitimi & 51 & 213.73 & & \\
\hline & Psikolojik Danışma ve Rehberlik & 68 & 237.73 & & \\
\hline & Okul Öncesi Eğitimi & 53 & 265.18 & & \\
\hline & Türkçe Eğitimi & 60 & 245.02 & & \\
\hline \multirow{8}{*}{$\begin{array}{c}\text { İletişim } \\
\text { İlkeleri } \\
\text { ve Temel } \\
\text { Beceriler } \\
\text { Alt } \\
\text { Boyutu }\end{array}$} & Sosyal Bilgiler Eğitimi & 66 & 290.36 & 11.178 & .131 \\
\hline & Bilgisayar ve Öğretim Teknolojileri Eğitimi & 34 & 275.76 & & \\
\hline & Sınıf Eğitimi & 97 & 266.01 & & \\
\hline & Fen Bilgisi Eğitimi & 75 & 230.36 & & \\
\hline & Matematik Eğitimi & 51 & 225.03 & & \\
\hline & Psikolojik Danışma ve Rehberlik & 68 & 233.38 & & \\
\hline & Okul Öncesi Eğitimi & 53 & 257.25 & & \\
\hline & Türkçe Eğitimi & 60 & 244.34 & & \\
\hline \multirow{8}{*}{$\begin{array}{l}\text { Kendini } \\
\text { İfade } \\
\text { Etme Alt } \\
\text { Boyutu }\end{array}$} & Sosyal Bilgiler Eğitimi & 66 & 296.55 & 9.253 & .235 \\
\hline & Bilgisayar ve Öğretim Teknolojileri Eğitimi & 34 & 265.31 & & \\
\hline & Sınıf Eğitimi & 97 & 246.90 & & \\
\hline & Fen Bilgisi Eğitimi & 75 & 245.12 & & \\
\hline & Matematik Eğitimi & 51 & 230.39 & & \\
\hline & Psikolojik Danışma ve Rehberlik & 68 & 236.93 & & \\
\hline & Okul Öncesi Eğitimi & 53 & 262.13 & & \\
\hline & Türkçe Eğitimi & 60 & 243.00 & & \\
\hline \multirow{8}{*}{$\begin{array}{c}\text { Etkin } \\
\text { Dinleme } \\
\text { ve Sözel } \\
\text { Olmayan } \\
\text { İletişim } \\
\text { Alt } \\
\text { Boyutu }\end{array}$} & Sosyal Bilgiler Eğitimi & 66 & 293.15 & 13.201 & .067 \\
\hline & Bilgisayar ve Öğretim Teknolojileri Eğitimi & 34 & 274.46 & & \\
\hline & Sınıf Eğitimi & 97 & 256.21 & & \\
\hline & Fen Bilgisi Eğitimi & 75 & 243.90 & & \\
\hline & Matematik Eğitimi & 51 & 203.74 & & \\
\hline & Psikolojik Danışma ve Rehberlik & 68 & 239.32 & & \\
\hline & Okul Öncesi Eğitimi & 53 & 265.20 & & \\
\hline & Türkçe Eğitimi & 60 & 245.27 & & \\
\hline \multirow{8}{*}{$\begin{array}{c}\text { İletişim } \\
\text { Kurmaya } \\
\text { İsteklilik } \\
\text { Alt } \\
\text { Boyutu }\end{array}$} & Sosyal Bilgiler Eğitimi & 66 & 281.83 & 6.137 & .524 \\
\hline & Bilgisayar ve Öğretim Teknolojileri Eğitimi & 34 & 264.49 & & \\
\hline & Sınıf Eğitimi & 97 & 249.66 & & \\
\hline & Fen Bilgisi Eğitimi & 75 & 228.95 & & \\
\hline & Matematik Eğitimi & 51 & 233.10 & & \\
\hline & Psikolojik Danışma ve Rehberlik & 68 & 251.32 & & \\
\hline & Okul Öncesi Eğitimi & 53 & 259.39 & & \\
\hline & Türkçe Eğitimi & 60 & 259.22 & & \\
\hline
\end{tabular}

Tablo 8 incelendiğinde, öğrenim görülen ana bilim dalı değişkenine göre İletişim Becerileri Genel Boyutu istatistiksel olarak anlamlı bir farklılık göstermediği görülmektedir (p>.05). İletişim Becerileri Ölçeği puan toplamları sıra ortalamaları incelendiğinde sosyal 
bilgiler eğitimi ana bilim dalı öğrencilerinin sıra ortalamalarının $(X=298,62)$ en yüksek, matematik eğitimi ana bilim dalı öğrencilerinin iletişim becerileri ölçeği puan toplamları sıra ortalamalarının $(X=213,73)$ en düşük olduğu görülmektedir.

Öğrenim görülen ana bilim değişkenine göre İletişim İlkeleri ve Temel Beceriler alt boyutu puan toplamları incelendiğinde istatistiksel olarak anlamlı bir farklılık olmadığ görülmektedir ( $p>.05)$. Sıra ortalamaları incelendiğinde sosyal bilgiler eğitimi ana bilim dalı öğrencilerinin sıra ortalamalarının $(X=290,36)$ en yüksek, matematik eğitimi ana bilim dalı öğrencilerinin İletişim İlkeleri ve Temel Beceriler alt boyutu sıra ortalamalarının $(X=225,03) \mathrm{en}$ düşük olduğu görülmektedir.

Öğrenim görülen ana bilim değişkenine göre Kendini İfade Etme alt boyutu puan toplamları incelendiğinde istatistiksel olarak anlamlı bir farklılık göstermediği görülmektedir ( $p>.05)$. Sıra ortalamaları incelendiğinde sosyal bilgiler eğitimi ana bilim dalı öğrencilerinin sıra ortalamalarının $(X=296,55)$ en yüksek, matematik eğitimi ana bilim dalı öğrencilerinin araştırmaya yönelik Kendini İfade Etme alt boyutu sıra ortalamalarının $(X=230,39)$ en düşük olduğu görülmektedir.

Öğrenim görülen ana bilim değişkenine göre Etkin Dinleme ve Sözel Olmayan İletişim alt boyutu puan toplamları incelendiğinde istatistiksel olarak anlamlı bir farklılık olmadığ görülmektedir ( $p>.05)$. Sıra ortalamaları incelendiğinde sosyal bilgiler eğitimi ana bilim dalı öğrencilerinin sıra ortalamalarının $(X=293,15)$ en yüksek, matematik eğitimi ana bilim dalı öğrencilerinin Etkin Dinleme ve Sözel Olmayan İletişim alt boyutu sıra ortalamalarının $(X=203,74)$ en düşük olduğu görülmektedir.

Öğrenim görülen ana bilim değişkenine göre İletişim Kurmaya İsteklilik alt boyutu puan toplamları incelendiğinde istatistiksel olarak anlamlı bir farklılık göstermediği görülmektedir ( $p>.05)$. Sıra ortalamaları incelendiğinde sosyal bilgiler eğitimi ana bilim dalı öğrencilerinin sıra ortalamalarının $(X=281,83)$ en yüksek, fen bilgisi eğitimi ana bilim dalı öğrencilerinin 
İletişim Kurmaya İsteklilik alt boyutu sıra ortalamalarının $(X=228,95)$ en düşük olduğu görülmektedir. Sınıf yönetimi yeterlikleri algılarına ilişkin alt boyutlar açısından öğrenim görülen ana bilim dalı değişkenine göre anlamlı farklılığın olup olmadığını belirlemek üzere yapılan analize ilişkin sonuçlar Tablo 9'da gösterilmiştir.

Tablo 9. Öğrenim görülen ana bilim dalı değişkenine göre sinıf yönetimi yeterlikleri algıları

\begin{tabular}{|c|c|c|c|c|c|}
\hline & Ana bilim Dalı & $\mathrm{n}$ & $\begin{array}{c}\text { Sira } \\
\text { Ortalamas1 }\end{array}$ & Ki-Kare & $\mathrm{p}$ \\
\hline \multirow{8}{*}{$\begin{array}{l}\text { Sinıf Yönetimi } \\
\text { Yeterlikleri Algıları } \\
\text { Genel Boyutu }\end{array}$} & Sosyal Bilgiler Eğitimi & 66 & 288.57 & 13.797 & .055 \\
\hline & Bilgisayar ve Öğretim Teknolojileri Eğitimi & 34 & 226.82 & & \\
\hline & Sınıf Eğitimi & 97 & 251.12 & & \\
\hline & Fen Bilgisi Eğitimi & 75 & 255.07 & & \\
\hline & Matematik Eğitimi & 51 & 210.77 & & \\
\hline & Psikolojik Danışma ve Rehberlik & 68 & 253.01 & & \\
\hline & Okul Öncesi Eğitimi & 53 & 226.85 & & \\
\hline & Türkçe Eğitimi & 60 & 283.94 & & \\
\hline \multirow{8}{*}{$\begin{array}{c}\text { Sinıfta İlişki } \\
\text { Yönetimi Alt Boyutu }\end{array}$} & $\begin{array}{l}\text { Sosyal Bilgiler Eğitimi } \\
\end{array}$ & 66 & 269.95 & 6.766 & .454 \\
\hline & Bilgisayar ve Öğretim Teknolojileri Eğitimi & 34 & 222.59 & & \\
\hline & Sınıf Eğitimi & 97 & 245.84 & & \\
\hline & Fen Bilgisi Eğitimi & 75 & 253.60 & & \\
\hline & Matematik Eğitimi & 51 & 221.59 & & \\
\hline & Psikolojik Danışma ve Rehberlik & 68 & 253.28 & & \\
\hline & Okul Öncesi Eğitimi & 53 & 276.50 & & \\
\hline & Türkçe Eğitimi & 60 & 263.84 & & \\
\hline \multirow{8}{*}{$\begin{array}{c}\text { Öğretim Yöntemi Alt } \\
\text { Boyutu }\end{array}$} & $\begin{array}{l}\text { Sosyal Bilgiler Eğitimi } \\
\end{array}$ & 66 & 304.13 & 22.293 & .002 \\
\hline & Bilgisayar ve Öğretim Teknolojileri Eğitimi & 34 & 236.74 & & \\
\hline & Sinıf Eğitimi & 97 & 255.98 & & \\
\hline & Fen Bilgisi Eğitimi & 75 & 254.13 & & \\
\hline & Matematik Eğitimi & 51 & 211.20 & & \\
\hline & Psikolojik Danışma ve Rehberlik & 68 & 227.71 & & \\
\hline & Okul Öncesi Eğitimi & 53 & 217.69 & & \\
\hline & Türkçe Eğitimi & 60 & 290.93 & & \\
\hline \multirow{8}{*}{$\begin{array}{l}\text { Öğrenciyi/Çevreyi } \\
\text { Tanıma Alt Boyutu }\end{array}$} & $\begin{array}{l}\text { Sosyal Bilgiler Eğitimi } \\
\end{array}$ & 66 & 276.96 & 20.785 & .004 \\
\hline & Bilgisayar ve Öğretim Teknolojileri Eğitimi & 34 & 233.79 & & \\
\hline & Sinıf Eğitimi & 97 & 254.15 & & \\
\hline & Fen Bilgisi Eğitimi & 75 & 249.19 & & \\
\hline & Matematik Eğitimi & 51 & 225.82 & & \\
\hline & Psikolojik Danışma ve Rehberlik & 68 & 285.98 & & \\
\hline & Okul Öncesi Eğitimi & 53 & 187.97 & & \\
\hline & Türkçe Eğitimi & 60 & 279.39 & & \\
\hline
\end{tabular}

Tablo 9 incelendiğinde, ana bilim dalı değişkenine göre sınıf yönetimi yeterlikleri algısının istatistiksel olarak anlamlı bir farklılık olmadığı görülmektedir ( $p>.05)$. Sınıf Yönetimi Yeterlilikleri Algısı Ölçeği puan toplamları sıra ortalamaları incelendiğinde sosyal 
bilgiler eğitimi ana bilim dalı öğrencilerinin sıra ortalamalarının $(X=288,57)$ en yüksek, matematik eğitimi ana bilim dalı öğrencilerinin Sınıf Yönetimi Yeterlilikleri Algısı ölçeği puan toplamları sıra ortalamalarının $(X=210,77)$ en düşük olduğu görülmektedir.

Ana bilim dalı değişkenine göre "Sınıfta İlişki Yönetimi” alt boyutu puan toplamları incelendiğinde, istatistiksel olarak anlamlı bir farklılık olmadığı görülmektedir ( $p>.05)$.Sınıfta İlişki Yönetimi alt boyutu puan toplamları sıra ortalamaları incelendiğinde okul öncesi eğitimi ana bilim dalı öğrencilerinin sıra ortalamalarının $(X=276,50)$ en yüksek, matematik eğitimi ana bilim dalı öğrencilerinin Sınıfta İlişki Yönetimialt boyutu puan toplamları sıra ortalamalarının $(X=221,59)$ en düşük olduğu görülmektedir.

Ana bilim dalı değişkenine göre "Öğretim Yöntemi” alt boyutu puan toplamları incelendiğinde, istatistiksel olarak anlamlı bir farklılık olduğu görülmektedir $(p<.05)$. Öğretim Yöntemi alt boyutu puan toplamları sıra ortalamaları incelendiğinde sosyal bilgiler eğitimi ana bilim dalı öğrencilerinin sıra ortalamalarının $(X=304,13)$ en yüksek, matematik eğitimi ana bilim dalı öğrencilerinin Öğretim Yöntemi alt boyutu puan toplamları sıra ortalamalarının $(X=211,20)$ en düşük olduğu görülmektedir. Öğretim yöntemi alt boyutunda görülen farklılığa ilişkin yapılan tamhane post hoc analizi sonucunda farklılığın sosyal bilgiler eğitimi ile matematik eğitimi, psikolojik danışma ve rehberlik ve okul öncesi eğitimi bölümü arasındaki farkl11ıktan kaynaklandığı görülmüştür $(p<.05)$.

Ana bilim dalı değişkenine göre "Öğrenciyi/Çevreyi Tanıma" alt boyutu puan toplamları incelendiğinde, istatistiksel olarak anlamlı bir farklılık olduğu görülmektedir ( $p<.05)$. Öğrenciyi/Çevreyi Tanıma alt boyutu puan toplamları sıra ortalamaları incelendiğinde psikolojik danışma ve rehberlik ana bilim dalı öğrencilerinin sıra ortalamalarının $(X=285,98)$ en yüksek, okul öncesi eğitimi ana bilim dalı öğrencilerinin Öğrenciyi/Çevreyi Tanıma alt boyutu puan toplamları sıra ortalamalarının $(X=187,97)$ en düşük olduğu görülmektedir. Öğrenciyi/Çevreyi tanıma alt boyutunda görülen farklılığa ilişkin yapılan tamhane post hoc 
analizi sonucunda farklılığın okul öncesi eğitimi ile psikolojik danışma rehberlik bölümü arasındaki farklılıktan kaynaklandığı görülmektedir (p<.05). İletişim becerilerine yönelik alg1 ile sınıf yönetimi yeterlikleri algısı arasındaki ilişkiye ait yapılan analiz sonuçları Tablo 10’da gösterilmiştir.

Tablo 10. Illetișim becerileri ile sınıf yönetimi yeterlikleri algısı

\begin{tabular}{|c|c|c|c|c|c|c|c|c|c|}
\hline & 1 & 2 & 3 & 4 & 5 & 6 & 7 & 8 & 9 \\
\hline \multicolumn{10}{|l|}{ 1)İletişim Becerileri Genel Boyutu } \\
\hline $\begin{array}{l}\text { 2)İletişim İlkeleri ve Temel Beceriler } \\
\text { Alt Boyutu }\end{array}$ & $.874^{* *}$ & & & & & & & & \\
\hline 3)Kendini İfade Etme Alt Boyutu & $.804^{* *}$ & $.578^{* *}$ & & & & & & & \\
\hline $\begin{array}{l}\text { 4)Etkin Dinleme ve Sözel Olmayan } \\
\text { İletișim Alt Boyutu }\end{array}$ & $.866^{* *}$ & $.685^{* *}$ & $.663^{* *}$ & & & & & & \\
\hline $\begin{array}{l}\text { 5)İletişim Kurmaya İsteklilik Alt } \\
\text { Boyutu }\end{array}$ & $.777^{* *}$ & $.541^{* *}$ & $.613^{* *}$ & $.582^{* *}$ & & & & & \\
\hline $\begin{array}{l}\text { 6)Sınıf Yönetimi Yeterlilikleri Algıları } \\
\text { Genel Boyutu }\end{array}$ & $.529^{* *}$ & $.456^{* *}$ & $.456^{* *}$ & $.489^{* *}$ & $.398^{* *}$ & & & & \\
\hline 7)Sınıfta İlişki Yönetimi Alt Boyutu & $.443^{* *}$ & $.402^{* *}$ & $.371^{* *}$ & $.418^{* *}$ & $.301^{* *}$ & $.833^{* *}$ & & & \\
\hline 8)Öğretim Yöntemi Alt Boyutu & $.486^{* *}$ & $.390^{* *}$ & $.429^{* *}$ & $.435^{* *}$ & $.420^{* *}$ & $.853^{* *}$ & $.559^{* *}$ & & \\
\hline $\begin{array}{l}\text { 9)Öğrenciyi/Çevreyi Tanıma Alt } \\
\text { Boyutu }\end{array}$ & $.430^{* *}$ & $.412^{* *}$ & $.350^{* *}$ & $.393^{* *}$ & $.297^{* *}$ & $.767^{* *}$ & $.502^{* *}$ & $.560^{* *}$ & \\
\hline
\end{tabular}

Tablo 10 incelendiğinde, iletişim becerileri genel boyutu ile sınıf yönetimi yeterlikleri algısı genel boyutu arasında pozitif yönlü orta kuvvette anlamlı bir ilişkinin olduğu görülmektedir ( $p<.05, r=, 529)$. İletişim becerileri ile sınıfta ilişki yönetimi alt boyutu arasında pozitif yönlü orta kuvvette anlamlı bir ilişkinin olduğu $(p<.05, r=, 443)$; öğretim yöntemi alt boyutu ile arasında pozitif yönlü orta kuvvette anlamlı bir ilişkinin olduğu $(p<.05, r=, 486)$; öğrenciyi/çevreyi tanıma alt boyutu ile arasında pozitif yönlü orta kuvvette anlamlı bir ilişkinin olduğu $(p<.05, r=, 430)$ görülmektedir.

\section{Tartışma, Sonuç ve Öneriler}

İletişimde başarılı bir öğretmenin sınıf yönetiminde hedefe ulaşacağını söylemek mümkündür. Çünkü öğrencileriyle iyi iletişim kurabilen bir öğretmen, sınıfta iyi ilişkiler kurulmasının, verimli bir öğretme-öğrenme ortamı oluşmasının, öğrencilerin yüksek düzeyde öğrenmelerinin ve olumlu davranışlar kazanmalarının yolunu açacaktır. Sınıf yönetiminde 
etkili olmak isteyen bir öğretmenin en önemli sorumluluklarından biri, öğrencilerle iyi iletişim kurmaktır. Ulaşılabilen alanyazında, öğretmen adaylarının iletişim becerileriyle sınıf yönetimi yeterlikleri arasındaki ilişkiyi ele alan yeterli sayıda çalışmaya rastlanmıştır. Bu araştırmanın amacı, öğretmen adaylarının iletişim becerileri ile sınıf yönetimi yeterlik algıları arasındaki ilişkinin incelenmesidir.

Araştırmada ilk olarak öğretmen adaylarının sınıf yönetimi yeterlikleri ve iletişim becerilerine ilişkin algılarının düzeyi belirlenmiş, öğretmen adaylarının her iki değişkene ilişkin algılarının yüksek düzeyde olduğu sonucuna ulaşılmıştır. Bir beceri, bir eyleme ilişkin yeterlik algısıyla o becerinin, eylemin başarı düzeyi arasında ilişki olduğu gerçeğinden hareketle, öğretmen adaylarının “Aday Öğretmenlerin Sınıf Yönetimi Yeterlikleri Ölçeği”nin geneli ve ölçeğin alt faktörlerinin tamamı ile “İletişim Becerileri Ölçeği”nin geneli ve ölçeğin alt faktörlerinin tamamına ilişkin algılarının yüksek düzeyde olduğu sonucunun olumlu bir sonuç olduğu ifade edilebilir (Schunk ve Gunn, 1986). Zira öğretmenin öğrencilerle iletişimde başarılı olması; öğrencilerin öğrenmeye, arkadaşlarına ve öğretmenlerine karşı olumlu tutum ve davranışlar sergilemeleri sonucunu doğurur; bu olumlu tutum ve davranışlar da sınıf yönetiminin amaçlarına ulaşılmasını sağlar (Jones ve Jones, 2001). İlgili literatür incelendiğinde, bir çok araştırmada benzer sonuçlara ulaşılmıştır. Yılmaz ve Altunbaş (2012) yürüttükleri bir araştırmada, iletişim becerisi yüksek olan öğretmen adaylarının sınıf yönetiminde de yüksek beceriye sahip olduğu sonucuna ulaşılmıştır. Konu ile ilgili Epçaçan ve Okçu (2009) ve Uşun (2005) tarafından yapılan bir başka araştırmada, sınıfta etkili iletişiminin sağlanmasında sözel ve beden dilinin etkin kullanılmasının en çok yararlanılan davranışlardan içerisinde yer aldığını belirlemişlerdir. Öğretmen seviyelerinin belirlenmesinin amaçlandığı Gündüz’ün (2001) araştırmasında, öğretmenlerin sınıf içindeki ilişki seviyelerini düzenlemede orta seviyede yeterliğe sahip oldukları sonucuna ulaşılmıştır. Benzer amaçla Gülünay (2012) 
tarafindan yapılan bir diğer araştırma sonucunda, öğretmenlerin sınıf yönetim becerilerinin yüksek olduğu bulgusuna ulaşılmıştır.

Araştırmada, “cinsiyet”in öğretmen adaylarının sınıf yönetimi yeterlik algıları ile iletişim becerileri algılarını etkilemeyen bir değişken olduğu sonucuna ulaşılmıştır. Araştırma bu sonucuyla, Tunçeli (2013), Bulut-Bozkurt (2004) ve Korkut ve Babaoğlan (2010) araştırmalarıyla benzerlik arz etmekte, Çetinkaya (2011) ile Nacar ve Tümkaya (2011) ile Yiğit, Aydın ve Küllü (2011) çalışmalarından ise ayrılmaktadır. Zira Tunçeli’nin (2013) ve BulutBozkurt'un (2004) araştırmalarında “cinsiyet” değişkeninin iletişim becerileri algılarında, Korkut ve Babaoğlan (2010) araştırmasında ise sınıf yönetimi becerileri algılarında anlamlı bir farklılık yaratmadığı, Çetinkaya (2011) ve Nacar ve Tümkaya'nın (2011) araştırmalarında ise cinsiyet değişkeninin iletişim becerileri algılarında ve Yiğit, Aydın ve Küllü’nün (2011) araştırmalarında ise sınıf yönetimi becerileri algılarında anlamlı bir farklılık yarattığı tespit edilmiştir. Benzer olarak Tan ve Tan (2016) tarafından yapılan araştırmada da ortalama puanlar açısından iletişim becerilerinin kadın öğretmen adaylarının lehine sonuçların ortaya çıktığı görülmüştür. Buna göre kadın öğretmen adayları, iletişim becerilerinde iyi oldukları bakış açısına daha çok katılmışlardır (Tan ve Tan, 2016). Bu bulgular 1şı̆̆ında kadın öğretmen adaylarının iletişim becerilerinin erkek öğretmen adaylarına ait iletişim becerilerinden daha yüksek seviyede olabileceği sonucuna varılabilir. Konu ile ilgili literatür incelendiğinde, Yılmaz ve Altunbaş (2012) ve Çiftçi ve Taşkaya (2010) tarafından yürütülen araştırmalarda eğitim fakültesinde öğrenim gören üniversite öğrencilerinin görüşlerinin cinsiyet değişkeni açısından sınıf yönetimi becerilerinde benzer iken, iletişim becerilerinde ise farklılık

Araştırmada, “öğrenim görülen bölümden memnuniyet”in öğretmen adaylarının iletişim becerileri algılarını etkilemeyen ancak sınıf yönetimi yeterlik algılarında istatistiksel olarak anlamlı farklılık yaratan bir değişken olduğu sonucuna ulaşılmıştır. Bu sonuç, öğrenim gördükleri bölümden memnun olan öğrencilerin öğretmenlik mesleki bilgi ve becerilerini 
kazanmayla ilgili daha fazla çalışma (araştırma, okuma vb.) kaynaklanıyor olabilir. Öğrenim görülen bölümden memnun olan öğrencilerin öğretmenlik mesleğine bağl1lık ve mesleki motivasyon düzeylerinin de yüksek olacağı düşünülebilir. Mesleğe bağlılık ve mesleki motivasyon düzeylerinin yüksek olması, öğrencilerin öğretmenlik yeterliklerini kazanma çabalarını artırmış olabilir.

Araştırmada, “öğrenim görülen ana bilim dalı”nın öğretmen adaylarının iletişim becerileri algılarını etkilemeyen bir değişken olduğu sonucuna ulaşılmıştır. Araştırma bu sonucuyla Kadalak Dölek (2015), Gürşimşek, Vural ve Demirsöz (2008) ve Şah’ın (2013) araştırmalarından ayrılmaktadır. Anılan araştırmalarda, Kadalak Dölek (2015), üniversite öğrencilerinin iletişim becerileri puan ortalamaları arasında öğrenim alanına göre anlamlı farkl1laşma olduğunu; Gürşimşek, Vural ve Demirsöz (2008) üniversite öğrencilerinin iletişim becerileri puan ortalamaları arasında öğrenim görülen programa göre anlamlı farklılaşma bulunduğunu ve Şah (2013) de üniversite öğrencilerinin iletişim becerileri puan ortalamaları arasında fakültelere göre anlamlı farklılık arz ettiğini tespit etmiştir.

Araştırmada, “öğrenim görülen ana bilim dalı”nın öğretmen adaylarının sınıf yönetimi yeterlikleri algılarında farklılaşmaya neden olmayan bir değişken olduğu sonucuna ulaşılmıştır. Araştırma bu sonucuyla Özer (2013) ve Özgan, Yiğit, Aydın, ve Küllük (2011) tarafından yapılan çalışmalarla paralellik arz etmektedir. Bu araştırmalarda; Özer (2013), öğretmen adaylarının sınıf yönetimi yeterlilik algıları arasında mezun olunan fakülte değişkenine göre anlamlı farklılık olmadığı sonucuna ulaşılmıştır. Branş değişkenine göre araştırma yapan diğer araştırma sonuçlarına göre, Tan ve Tan (2016) tarafından 4. Sınıf öğretmen adayları ile yapılan araştırmada öğrenim görülen ana bilim dalı değişkeninin anlamlı şekilde farklılaşmadığ sonucunda ulaşılırken, Özgan, Yiğit, Aydın, ve Küllük (2011) tarafından yürütülen araştırmada da ilkokul ya da ortaokulda çalışan farklı branşlardaki öğretmenlerin sınıf yönetimine ilişkin görüşlerinde anlamlı farklılığın olmadığı görülmüştür. 
Araştırmada son olarak öğretmen adaylarının iletişim becerileri ve sınıf yönetimi yeterliklerine ilişkin algıları arasındaki ilişki düzeyi belirlenmiş ve bu iki değişsen arasında pozitif yönlü orta kuvvette anlamlı bir ilişki olduğu belirlenmiştir. Diğer bir ifade ile öğretmen adaylarında iletişim becerileri algı düzeyi yükseldikçe sınıf yönetimi yeterlik algı düzeyi de yükselmektedir. Buradan hareketle sınıf yönetimi yeterliklerini yüksek düzeyde sergileyen bir öğretmen adayının iletişim becerileri düzeyinin de yüksek olacağını, iletişim becerileri yüksek düzeyde olan bir öğretmen adayının da sınıf yönetimi yeterliklerini yüksek düzeyde gerçekleştirebileceğini söylemek mümkündür.

\section{Öneriler}

- Araştırmada, “öğrenim görülen bölümden memnuniyet”in öğretmen adaylarının iletişim becerileri algılarını etkilemeyen ancak sınıf yönetimi yeterlik algılarında istatistiksel olarak anlamlı farklılık yaratan bir değişken olduğu sonucuna ulaşılmıştır. Öğretmen adaylarının iletişim becerileri algılarını etkileyen diğer değişkenleri tespit etmeye yönelik çalışmalar yapılabilir.

- Araştırmada, “öğrenim görülen ana bilim dalı”nın öğretmen adaylarının sınıf yönetimi yeterlikleri algılarında farklılaşmaya neden olmayan bir değişken olduğu sonucuna ulaşılmıştır. Öğretmen adaylarının sınıf yönetimi yeterlikleri algılarını etkileyen diğer değişkenleri tespit etmeye yönelik çalışmalar yapılabilir.

- Öğretmenlerin sınıf yönetimi yeterlikleri ve iletişim becerilerine ilişkin algıları arasında pozitif yönlü orta kuvvette bir ilişki olduğu bulgusundan hareketle öğretmenlere ve öğretmen adaylarına yönelik gerek hizmet öncesinde gerekse iş başında sınıf yönetimi yeterlikleri ve iletişim becerilerini geliştirmeye yönelik dersler, kurslar, sosyal ve kültürel etkinlikler gerçekleştirilebilir. 
- Mevcut sonuçların genellenebilmesi için daha fazla Türkçe öğretmeniyle çalışma yapilmalidir.

- Aynı ilişkisel araştırma, farklı eğitim fakültelerinde, farklı öğretmen adayları grupları üzerinde gerçekleştirilebilir.

- Her ne kadar araştırma sonucunda nitelikli bulgulara ulaşılsa da bireylerin İletişim Becerileri ile Sınıf Yönetimi Yeterlik Algı düzeylerinin artırılması amacıyla sonraki araştırmalarda deneysel yöntemlerin kullanıldığı araştırma yöntemleri tercih edilebilir.

- Öğretmen adaylarının iletişim becerileri ve sınıf yönetimi yeterliklerini etkileyen etkenlerin neler olduğunu tespit etmeye yönelik nitel araştırmalar yapılabilir.

- Araştırma sonuçlarını daha detaylı inceleyebilmek adına nicel ve nitel araştırmaların birlikte kullanıldığg karma yöntemleri araştırma kalitesini daha da iyileştirebilir.

\section{Makalenin Bilimdeki Konumu (Yeri)}

Eğitim Bilimleri Bölümü, Eğitim Programları ve Öğretim Ana bilim Dalı

\section{Makalenin Bilimdeki Özgünlüğü}

İletişimde başarılı bir öğretmenin sınıf yönetiminde hedefe ulaşacağını söylemek mümkündür. Çünkü öğrencileriyle iyi iletişim kurabilen bir öğretmen, sınıfta iyi ilişkiler kurulmasının, verimli bir öğretme-öğrenme ortamı oluşmasının, öğrencilerin yüksek düzeyde öğrenmelerinin ve olumlu davranışlar kazanmalarının yolunu açacaktır. Sınıf yönetiminde etkili olmak isteyen bir öğretmenin en önemli sorumluluklarından biri, öğrencilerle iyi iletişim kurmaktır. Ulaşılabilen alanyazında, öğretmen adaylarının iletişim becerileriyle sınıf yönetimi yeterlikleri arasındaki ilişkiyi ele alan yeterli sayıda çalışmaya rastlanmıştır. Bu araştırmanın amacı, öğretmen adaylarının iletişim becerileri ile sınıf yönetimi yeterlik algıları arasındaki ilişkinin incelenmesidir. Çalışmanın bu niteliği ile alanyazına katkı sağlayacağı düşünülmektedir. 


\section{Kaynakça}

Ateş, H. \& Durmaz, S. (2016). Fen bilgisi öğretmen adaylarının öz-değer inançlarının bazı değişkenler açısından incelenmesi. Kırşehir Üniversitesi Eğitim Fakültesi Dergisi, 17(1), 517-533

Aypay, A. (2010). Genel Öz Yeterlik Ölçeği’nin (GÖYÖ) Türkçe ’ye uyarlama çalışması. İn̈nü Üniversitesi Eğitim Fakültesi Dergisi, 11(2), 113-131.

Başaran, İ.E. (2005). Ĕ̆itim psikolojisi gelişim, öğrenme ve ortam. Ankara: Nobel Yayıncılık.

Brophy, J. (1988). Educating teachers about managing classrooms and students. Teaching and teacher education. 4 (1), 1-18.

Bulut- Bozkurt, N. (2004). İlköğretim Sınıf Öğretmenlerinin İletişim Becerilerine İlişkin Algılarının Çeşitli Değişkenler Açısından İncelenmesi. Türk Eğitim Bilimleri Dergisi,2 (4), 443- 454.

Büyüköztürk, Ş., Çakmak, E. K., Akgün, Ö. E., Karadeniz, Ş., \& Demirel, F. (2010). Bilimsel Araştırma Yöntemleri. Ankara: Pegem Akademi.

Celep, C. (2002). Sinıf yönetimi ve disiplini. Ankara: Anı Yayıncılık.

Cüceloğlu, D. (2002). Illetişim donanımları. İstanbul: Remzi Kitabevi.

Cüceloğlu, D., (2016). Yeniden insan insana. İstanbul: Remzi Kitabevi.

Çetinkaya, Z. (2011). Türkçe öğretmen adaylarının iletişim becerilerine ilişkin görüşlerinin belirlenmesi. Kastamonu Ĕgitim Dergisi,19(2), 567-576.

Çiftçi, S. ve Taşkaya, S. M. (2010). Sınıf öğretmeni adaylarının öz yeterlik ve iletişim becerileri arasındaki ilişki. e-Journal of New World Sciences Academy, (5), 3.

Demirel Ö. (2006). Öğretimde planlama ve değerlendirme öğretme sanatı. Ankara: Pegem Akademi Yayıncılık.

Demirtaş, H. (2009). Sınıf yönetiminin temelleri. In, Hüseyin K. (Ed.). Etkili sınıfyönetimi. An1 Yayınc1lık, Ankara.

Erdoğan, İ. (2010). Sinıf yönetimi. İstanbul: Sistem Yayıncılık.

Fraenkel, J. R., \& Wallen, N. E. (2009). How to design and evaluate research in education (7th ed.). New York: McGraw-Hill Higher Education.

Gordon, T. (1996) Etkili Öğretmenlik Ĕgitimi, İstanbul: Sistem Yay.

Gökyer, N., \& Özer, F. (2014). Aday öğretmenlerin sınıf yönetimi yeterliliklerine ilişkin alg1lar1. Turkish Studies-International Periodical For The Languages, Literature and History of Turkish or Turkic, 9(2), 691-712. 
Gülünay S. (2012). İlköğretim öğretmenlerinin sınıf yönetimi eğilimlerinin belirlenmesi.Yayınlanmamış Yüksek Lisans Tezi. Ankara: Ankara Üniversitesi Eğitim Bilimleri Enstitüsü.

Gündüz, Y. (2001). Öğretmenlerin sinıf yönetimindeki yeterlikleri. Yayımlanmamış Yüksek Lisans Tezi İstanbul: Yıldız Teknik Üniversitesi Sosyal Bilimler Enstitüsü Gürşimşek, I. (1999). Etkin sınıf yönetimi için etkili iletişim becerileri. Eğitim ve Bilim, 23, 4044.

Gürşimşek, I., Vural, D. E., \& Demirsöz, E. S. (2008). Öğretmen adaylarının duygusal zekâları ile iletişim becerileri arasındaki ilişki. Mehmet Akif Ersoy Üniversitesi Eğitim Fakültesi Dergisi, 8(16), 1-11.

Gürüz, D.,\& Temel-Eğinli, A. (2013). İletişim becerileri. Ankara: Nobel Akademik Yayıncılık. İlgar, L. (2005). Ĕ̈itim yönetimi okul yönetimi sınıf yönetimi (3. Baskl). İstanbul: Beta Yayıncilik.

İnceoğlu, M. (2004). Tutum, algı, iletişim. Ankara: Elips Kitap.

Jones, V.F. ve Jones, L.S. (2001). Comprehensive classroom management: craeting communities of support and solving problems. Allyn and Bacon, Boston, USA.

Kadalak Dölek, A. (2015). Üniversite ögrencilerinin iletişim becerilerinin farklı değişkenler açısından incelenmesi.(Yayınlanmamış Yüksek Lisans Tezi). Atatürk Üniversitesi Eğitim Bilimleri Enstitüsü, Erzurum.

Korkut, K., \& Babaoğlan, E. (2010). Sınıf öğretmenlerinin sınıf yönetimi becerisi. Dumlupınar Üniversitesi Sosyal Bilimler Dergisi, 10(26), 146-156.

Kuğuoğlu, İ. H.(2005). Sinıf öğretmenliği bölümü mezunu aday öğretmenlerin kendi algılamalarına göre sınıf yönetimi alanındaki yeterliliklerine dair görüşleri ve öneriler. Kazım Karabekir Ĕ̈itim Fakültesi Dergisi, 11,214-236.

Küçük, M. (2012). Illetişim kavramı ve iletişim süreci. İçinde, Nezih O. ve Ufuk E. (Ed.) Illetişim bilgisi. Eskişehir: Anadolu Üniversitesi Yayını.

Lasswell, H.D. (2007). The structure and function of communication in society. Illetişim kuram ve araştırma dergisi, 24, 215-228.

Lemlech, J.K. (1988). Classroom management(Second Edition). Longman Inc., New York.

Levent, O. (2011). İlköğretim fen ve teknoloji, matematik öğretmenlerinin eğitime ve sınıf yönetimine ilişkin inançları arasındaki ilişki. Pegem Eğitim ve Öğretim Dergisi, 1(4), $39-51$. 
Nacar, F. S., \& Tümkaya, S. (2011). Sınıf öğretmenlerinin iletişim ve kişilerarası problem çözme becerilerinin incelenmesi. Illköğretim Online, 10(2), 493-511.

Okçu, V. (2006). İlköğretim okulu yönetici ve öğretmenlerinin toplam kalite yönetimine ilişkin yönelimleri. Yayımlanmamış Yüksek Lisans Tezi. Eskişehir: Anadolu Üniversitesi Eğitim Bilimleri Enstitüsü

Okut, L. (2011). İlköğretim fen ve teknoloji, matematik öğretmenlerinin eğitim ve sınıf yönetimine ilişkin inançları arasındaki ilişki. Pegem Ĕ̆itim ve Öğretim Dergisi, 1(4), $39-51$.

Oskay, Ü. (1999). İletişimin abc'si. İstanbul: Der Yayınları.

Owen, F. K., \& Bugay, A. (2014). İletişim becerileri ölçeği'nin geliştirilmesi: geçerlik ve güvenirlik çalışması. Mersin Üniversitesi Eğitim Fakültesi Dergisi, 10(2),51-64.

Özay Köse, E. (2010). Sınıf yönetimine yönelik öğretmen adaylarının görüşleri. Çukurova Üniversitesi Ĕ̈itim Fakültesi dergisi, 3(39) 20-27.

Özer, F. (2013). Aday öğretmenlerin sınıf yönetimi yeterliliklerine ilişkin algıları.(Yayınlanmamış Yüksek Lisans Tezi). Fırat Üniversitesi Eğitim Bilimleri Enstitüsü, Elâzı̆̆.

Özgan, H., Yiğit, C., Aydın, Z. \& Küllük M. C. (2011). Ilköğretim okulu öğretmenlerinin sınıf yönetimine ilişkin algılarının incelenmesi ve karşılaştırılması. Sosyal Bilimler Dergisi,10(1), 615- 635.

Sadık, F. (2000). Illköğretim 1. aşama sınıf öğretmenlerinin sınıfta gözlemledikleri problem davranışlar.(YayımlanmamışYüksek Lisans Tezi). Çukurova Üniversitesi Sosyal Bilimler Enstitüsü, Adana.

Schunk, D.H. ve Gunn, T.P. (1986). Self-efficacy and skill development: influence of task strategies and attributions. Journal of Educational Research. 79(4), 238-244.

Şah, N. (2013). Üniversite öğrencilerinin iletişim becerileri ile akademik öz yeterlikleri arasındaki ilişkinin incelenmesi.(Yayınlanmamış Yüksek Lisans Tezi). Gaziantep Üniversitesi Eğitim Bilimleri Enstitüsü, Gaziantep.

Tan, Ç \& Tan, S. (2016). Öğretmen adaylarının iletişim becerileri ile sınıfı yönetme becerileri arasındaki ilişkinin incelenmesi. E-Kafkas Ĕ̆itim Araştırmaları Dergisi, 3(3), 1-14.

Tanrıkulu B. (2002). İnsan kaynakları yönetiminin etkinliğinde iletişimin rolü. Çağın Polisi dergisi. http://www.caginpolisi.com.tr/insan-kaynaklari-yonetiminin-etkinligindeiletisimin-rolu-2/ adresinden 19 Temmuz 2017 tarihinde alınmıştır. 
TDK (2017). Türk Dil Kurumu Güncel Türkçe Sözlük. http://www.tdk.gov.tr. adresinden 9 Kasım 2017 tarihinde alınmıştır.

Tunçeli, H. İ. (2013). Öğretmen adaylarının iletişim becerileri ile öğretmenlik mesleğine yönelik tutumları arasındaki ilişkinin incelenmesi. Pegem Ĕ̆itim ve Öğretim Dergisi, $3(3), 51-58$.

Tutar, H., \&Yılmaz, K. M. (2010). Genel iletişim kavramlar ve modeller. Ankara: Seçkin Yayınc1lik.

Usluata, A. (1995). İletişim. İstanbul: İletişim Yayınları.

Uşun, S. (2005). “İlköğretim Birinci Kademe (sınıf) Öğretmenlerinin Öğrenme Öğretme Sürecindeki Davranışlarının İncelenmesi.” XIV. Ulusal Eğitim Bilimleri Kongresi. Bildiri Özetleri. 28-30 Eylul. Cilt II. S. 46-50. Denizli: Pamukkale Üniversitesi.

Yılmaz, N. ve Altunbaş, S. (2012). Öğretmen adaylarının iletişim becerileri ile sınıf yönetimi becerilerinin incelenmesi. Erzincan Üniversitesi Ĕ̈itim Fakültesi Dergisi, 14(1).

\section{Summary}

Problem Statement: Today, one of the most important skills expected from teachers is to have an effective communication with all the people they interact with, especially their colleagues, school administrators, students and students' families. It is a very important factor for teachers to be effective communicators in terms of the development of relationships among shareholders, development of schools and increase of the quality of education. It can be argued that the solution of many problems experienced in education depends on the success of teachers in communication.In this context, it is of utmost importance that preservice teachers acquire communication skills, use communication skills effectively and specialize in communication. A teacher's possession of communication skills and ability to use communication skills can prepare the ground for success in classroom management and achievement of goals. Because teachers who effectively communicate with their students in the classroom can ensure that good relations are established in the classroom, a productive learning-teaching environment is established and that students acquire a high level learning and positive behaviors. On the other 
hand, a teacher who is sufficient in classroom management is expected to communicate well with students in the class. As a matter of fact, one of the most important aspects of classroom management and competency in classroom management is communication; a good communication.A competent teacher in classroom management plans teaching; organizes the resources required for teaching; co-ordinates between students and student clusters; controls teaching activities and students' learning; measures and evaluates learning deeds of students. $\mathrm{He} / \mathrm{she}$ also establishes the teacher-student and student-student communication.

Purpose of the Study: Despite the fact that there are studies in the reachable literature examining preservice teachers' communication skills and classroom management competencies separately; there is only one study embracing the relationship between preservice teachers 'communication skills and classroom management competencies. It is important to examine the relationship between communication skills and classroom management competencies, which are considered to be two important variables affecting the quality in education.The main purpose of this study is to reveal the relationship between preservice teachers' communication skills and classroom management competency perceptions. According to that purpose, the problem statement of the study is; "Is there a statistically significant relationship between preservice teachers 'communication skills and classroom management competency perceptions?"

$\operatorname{Method}(\mathbf{s})$ :The study is a correlational study aimed to determine the relationship between preservice teachers' communication skills and classroom management competency perceptions. Working group of the study consists of 385 (76.4\%) female and 119 (23.6\%) male students selected via convenience sampling method. Personal information form, Communication Skills Scale and Preservice Teachers' Classroom Management Competency Scale were used as data collection tools in the study.The data were processed in the SPSS package software and normality tests were performed to determine the tests to be used in the 
study. The Shapiro-Wilk normality test is required to be used for groups with a working group larger than 50 people. According to the results of the Shapiro-Wilk normality test, it was understood that the data were not normally distributed. Because the data were not normally distributed, non-parametric tests were used for the data analysis; Mann Whitney U test for twocategory variables; Kruskal Wallis test for analyzing the variables with three and more categories; and the Spearman Correlation analysis for analyzing the effects of variables on each other.

Findings and Discussions: The following results were obtained in the study; preservice teachers had high levels of communication skills and classroom management competency perceptions, there was no statistically significant difference in the levels of communication skills and classroom management competency perceptions according to the variable of "gender", no statistically significant difference in the level of communication skills perceptions according to the variable of "satisfaction with graduation department", there was a statistically significant difference in the level of classroom management competency perceptions according to the variable of "satisfaction with department", no statistically significant difference in the level of communication skills perceptions according to the variable of "department", a statistically significant difference in the perception level in "Teaching Management" and "Knowing the Student/Environment" sub-factors of classroom management competencies according to the variable of "department" and there was a positively moderate and significant relationship between communication skills perceptions and classroom management competency perceptions.

Conclusions and Recommendations: At the end of the study, it was concluded that there was no significant difference in communication skills and classroom management perceptions according to the variable of "gender"; no statistically significant difference in the levels of communication skills according to the variable of "satisfaction with graduation department"; a 
statistically significant difference in classroom management competency perceptions on behalf of those who were satisfied with their departments; no significant difference in communication skills and classroom management perceptions according to the variable of "department" and there was a positively moderate and significant relationship between communication skills perceptions and classroom management competency perceptions, in other words, the increasing communication skills led to an increase in classroom management competency perceptions. Classroom management is a mandatory and common course in the education faculties in Turkey. As seen in the findings of this study, it has been determined that there is a positively moderate relationship between communication skills and classroom management competencies. The reason why this relationship is moderate may be that the classroom management course is a theoretical course. In this context, classroom management courses can be applied practically in all education programs in education faculties. The course hours of classroom management courses can also be extended to develop the intraclass communication skills of preservice teachers. This course can be supported by other courses such as body language, group communication or effective speaking. It can be advised to other researchers who want to work on the same topic to produce mixed-pattern studies aimed to predict factors affecting classroom management and communication skills.

Keywords: Teacher education, communication skills, classroom management. 